\title{
Constructing the Monstrous Body in Beowulf
}

\begin{abstract}
:
The monstrosity of Grendel and his mother have long held the interest of Beowulf-scholars. Examining the bodily attributes of both figures in order to detect inter-textual patterns of diction, this article focuses on depictions of the monsters' skin, hands and blood. In analyzing these attributes, it becomes clear that the Beowulf-poet's chosen descriptors align the monstrous body with manmade objects in general and with weapons and armour in particular. This blurring of body and human artifact creates an environment for monstrous existence that is between and outside of both human culture and nature.
\end{abstract}

The Old English poetic world is intensely focused upon human experience. It thus comes as no surprise that when objects take centre stage, Old English poets frequently emphasize their constructed nature. ${ }^{1}$ Indeed, it is this process of human construction that makes created objects worthy of mention at all. Their manmade status elevates them, doing so all the more when their construction requires great effort and skill. A typical example of this sort of skilled construction relates to weapons and armour, which are among the most prominent treasures in Old English literature. ${ }^{2}$ While references to all manner of metals abound in Old English, poetic depictions imply not that their value lies in the metals themselves (except perhaps for their raw potential), but rather in their ability to be manipulated into useful objects. ${ }^{3}$ Hence, references to twisted, beaten and adorned metals far outstrip mentions of pure metals, with a whole subset of riddles exploring this process in particular. ${ }^{4}$ Depictions of weapons and armour especially demonstrate the association between the value of worldly wealth and human skill when they are personified, moving beyond high status objects to become valued heroic companions. ${ }^{5}$ Discussing created objects such as these, Fred C. Robinson has particularly emphasized their symbolic value, arguing that they become comforting images because of their representation of 'the ability of man, through skill and reason, to subdue and control the natural world'. ${ }^{6}$ It is, thus, the human realm of civilization 
and knowledge that is seen to determine the value of every object, animal or person in the Anglo-Saxon world.

A flipside to the frequent personification of objects is the objectification of the human body, again a commonplace in Old English poetry. From an understanding of human physiology in terms of its attachments - something that demonstrates a conceptual link to Old English understandings of manmade constructions - it is easy to see how the metaphor of the body-as-building came to be so prevalent in medieval writing. ${ }^{7}$ We can see this metaphor at the lexical level in examples of 'body' terms, such as banhus ${ }^{8}$ and bansele, ${ }^{9}$ as well as in large-scale sets of imagery, including those discussed by Joyce Tally Lionarons in her survey of prominent Old English and Old Norse parallels. ${ }^{10}$ It is perhaps unsurprising that the cultural world of construction should map on to the natural world of the body in this metaphorical manner, because for the Anglo-Saxons the worlds of culture and nature were frequently opposed. ${ }^{11}$ The written record depicts culture, represented by manmade buildings and artefacts, as under constant attack by nature, the chaotic world existing outside of civilization — a world that could not be kept under human control. Thus, the Old English literary tendency to depict the body in the terms of a cultural product makes a great deal of sense; the body cannot be entirely denied because it is inseparable from human life, yet to align it with the natural world would produce a conflict with the anti-natural world attitude depicted in Anglo-Saxon writings. And so, the body is instead translated into the language of culture.

Given the tension between nature and culture and the alliance it produces between humans and manmade objects, a problem arises in the form of where to place the humanoid monster. ${ }^{12}$ The developing field of monster theory has for some years now been tracing the similarities and differences perceived by various human groups regarding this categorical 'Other', with the medieval world providing a particularly stimulating context for discussion. 
Thus, Jeffrey Jerome Cohen argues that monsters 'are disturbing hybrids whose externally incoherent bodies resist attempts to include them in any systematic structuration. And so the monster is dangerous, a form suspended between forms that threatens to smash distinctions'. ${ }^{13}$ As Jennifer Neville notes, this ability to smash distinctions makes the monster a force that subverts humanity, afflicting not merely the individual, but society at large. ${ }^{14} \mathrm{In}$ doing so, the monster is aligned with the natural world and placed in opposition to humanity and the constructed world of civilization. It would follow logically, then, that the monstrous body should be described in naturalistic terms - in terms as different from the human body and human construction as possible. And yet this is not always the case.

Indeed, as with the Riddles, whose personification of corporeal objects leads to all manner of monstrous creatures straining for freedom from their human yoke, in Beowulf - the particular focus of this paper-depictions of Grendel and his mother frequently blur the line between body and object. These characters' monstrous bodies echo the valued artifacts of the human world, to the extent that they embody the precious objects of armour and weaponry. ${ }^{15}$ In these depictions, the monstrous body is a living artifact, a poetic construction made out of the treasures of humankind. By looking at such a juxtaposition of object and body, this paper will examine the various physical characteristics of Grendel and his mother-including their skin, hands and blood — that place the monstrous body in a space between and outside of both human culture and nature.

\section{IMPENETRABLE SKIN}

Despite Grendel's shadowy entrance in the poem, ${ }^{16}$ early on the Beowulf-poet draws attention to parts of the monster's body, whether directly or indirectly. The grasping fingers that will be dealt with later in this paper offer direct access to the monstrous body, while the skin-if, 
indeed, it is described at all—most certainly falls into the category of circumlocution. The first of several vague allusions to Grendel's impenetrability occurs during his battle with Beowulf. The hero has, notably, vowed not to kill Grendel by the sword - though he claims he could do so easily in lines $679-80$ - because Nat he para goda.${ }^{17}$ This statement has been understood to mean that Grendel does not know how to use a sword, ${ }^{18}$ indicating something of Beowulf's moral fibre in leveling the playing field, as well as his own concern for gaining glory through a demonstration of his physical prowess. However, it also implies that the hero has unwittingly overcome a particularly problematic feature of Grendel's defenses: he cannot be pierced by swords. The poet quite clearly states this fact several hundred lines later when Beowulf's men attempt to aid him in combat:

Hie pæt ne wiston, pa hie gewin drugon, heardhicgende hildemecgas, ond on healfa gehwone heawan pohton, sawle secan: pone synscaðan ænig ofer eorpan irenna cyst, guðbilla nan, gretan nolde. ${ }^{19}$

These and the preceding lines clearly indicate that Beowulf and his men believe their swords capable of affecting Grendel when, in fact, they are not. ${ }^{20}$ The reason for this sword-failure is less clear:

ac he sigewæpnum forsworen hæfde, ecga gehwylcre. ${ }^{21}$

The ambiguity of the referent, he, allows for the possibility that the line could be applied to either Grendel or Beowulf, something that the $D O E$ entry for forswerian points out: to forswear, abjure, renounce (weapons dat.); the passage has been much discussed and the verb often translated contextually as 'to make useless by a 
spell / to bewitch', with the subject he taken to refer to Grendel and $a c$ translated as 'because': 'no battle-sword could touch the miscreant because he [Grendel] had bewitched the weapons'; however, much of the evidence for this reading rests on an apparent misinterpretation of CorpGl 24.84 (cf. sense 3 below) and the sense 'to forswear, renounce' is more persuasive both lexicographically and contextually; translate either 'but he [Grendel] forswore weapons'; or, more plausibly, (translating $a c$ as 'but' and he as ref. back to Beowulf) 'no battle-sword could touch the miscreant; but he [Beowulf] had forsworn weapons'.22

Alluding to the variety of scholarly approaches to these lines, the $D O E$ editors argue against a commonly asserted view that this passage refers to Grendel's ability to work magical spells. However, the editors of Klaeber Four prefer the magic interpretation, noting that 'renounced' is an attested meaning for the verb in Middle English, rather than Old English, and further that the verb's dative object may indicate a different a sense than usual. ${ }^{23}$

That being said, given the sheer scale of legal diction depicting Grendel as a criminal or taking part in a feud, ${ }^{24}$ the more literal and legalistic reading of forswerian as 'swear away', 'renounce' or 'abjure' still holds value. This line could refer metaphorically to Grendel's monstrosity, which is seen as stemming from his association with the devil, giants and the race of Cain - all of whom are depicted elsewhere as enemies and oath-breakers in a feud against God—rather than as a natural occurrence. ${ }^{25}$ Hence, it is unclear whether or not Grendel's impenetrability is the result of direct magical invocation.

Others have argued that this particular feature stems from wider Germanic tradition, connecting it to tales about berserkers and wild animals, especially the bear. ${ }^{26}$ Similarly, reading the later mention of Grendel's glof in lines 2085b-91a as a reference to the monster's belly, Andrew M. Pfrenger argues that Grendel's skin is either covered with or composed of 
armoured scales. ${ }^{27}$ According to this interpretation, the poetic wordplay regarding hands is extended to the monster's swollen stomach, which is identified as a glove into which its victims are stuffed. Pfrenger then interprets references to the glof as searobendum faest $t^{28}$ and

$$
\begin{aligned}
& {[\ldots] \text { orðoncum eall gegyrwed }} \\
& \text { deofles craeftum }
\end{aligned}
$$

in relation to armour: 'As I read the passage, there are two possible solutions. The first is that Grendel wears something like a coat of mail over his skin which is then held closed by these cunning clasps or cinched by the belt. The second, and my preference, is that Beowulf is describing the strange looking skin on the monster looming over him'.${ }^{30}$ Pfrenger's argument that the glof refers to Grendel's literal belly perhaps pushes the text too far. The verse unit Glof hangode ${ }^{31}$ is unlikely to indicate a sagging belly, as Pfrenger would have it; the verb does not act this way elsewhere in Beowulf and other Old English literature, but instead is used of objects or whole bodies which hang from something else. ${ }^{32}$ However, although I disagree with Pfrenger's premise, I do think there is value in the attention he draws to the parallel diction of human and monstrous construction. For example, the use of the same verb, gyrwan, 'to adorn', in both the description of Beowulf arming himself in lines 1441b-2 and the construction of the glof in line $2087 \mathrm{~b}$ points to an identification between the tools of the hero and those of the monster. Indeed, (ge)gyrwan, with its general meaning of adornment or preparation, is frequently invoked in the context of the body in Old English literature, either in relation to the taking up of arms or to clothing a person. ${ }^{33}$ Thus, the line between the human and monstrous bodies is blurred by the use of shared diction describing their preparation for battle.

Furthermore, if we read the above allusions to Grendel's impenetrability alongside later references to his mother, we find a useful context for understanding the bodies of both monsters. Although Beowulf took on Grendel sword-less, the hero is less adventurous in his 
battle with Grendel's mother. ${ }^{34}$ Fully-armoured, Beowulf fights Grendel's mother with a borrowed sword, which inevitably fails:

$$
\text { mægenræs forgeaf }
$$

hildebille, hond sweng ne ofteah, pæt hire on hafelan hringmæl agol grædig guðleoð. (Đ)a se gist onfand pæt se beadoleoma bitan nolde, aldre scepðan, ac seo ecg geswac ðeodne æt pearfe..$^{35}$

This passage quite clearly depicts not simply a general aversion between monstrous body and sword, but rather an inability for the sword to penetrate the body. The reason for this seems to be not magic but the similarity between skin and armour. Indeed, through the overlapping use of diction applied to both, a direct analogy is made between Grendel's mother's skin and the war-gear that Beowulf's men wear upon their arrival at Heorot earlier in the poem. In that passage, the noisy shuffling of weapons and armour is referred to by the phrase, song in searwum, ${ }^{36}$ not unlike the guðleoð, 'war-song', that Beowulf's sword makes as it glances off Grendel's mother's head in the passage above. The shared reference to such battle songs indicates a poetic link between Grendel's mother's impenetrable skin and the metal of manmade armour. This alignment is strengthened further by a reference to Beowulf's own helmet only a few lines earlier:

$$
\begin{aligned}
& \text { ac se hwita helm hafelan werede, } \\
& \text { se pe meregrundas mengan scolde, } \\
& \text { secan sundgebland since geweorðad, } \\
& \text { befongen freawrasnum, swa hine fyrndagum } \\
& \text { worhte wæpna smið, wundrum teode, }
\end{aligned}
$$


besette swinlicum, pæt hine syðpan no

brond ne beadomecas bitan ne meahton. ${ }^{37}$

The language of impenetrability assigned to the carefully-wrought helmet is strikingly similar to that of Grendel's mother's bare head, with the same verb, bitan, 'to bite', employed in relation to both. The $D O E$ gives five instances where bitan means 'to cut or penetrate with a weapon or sharp object', ${ }^{38}$ each of which depicts the striking of an armoured or otherwise tough object. In addition to the instances above, bitan is invoked in relation to shields in Riddles $5^{39}$ and $93 .{ }^{40}$ The verb is also invoked in the context of Riddle 93's inkhorn, ${ }^{41}$ which shares a fate similar to the shield — both being hard objects that suffer from the blows of sharp edges. Finally, bitan occurs again in Beowulf at line $2578 \mathrm{~b}$ where it relates to the hero's inability to penetrate the dragon's almost entirely invulnerable body. Thus Grendel's mother is aligned with not only armour and shields in the wider world of Old English poetry, but also with another toughened, monstrous body in Beowulf. Although there is no mention of Grendel's mother forswearing weapons, it appears that no sword other than the giant-wrought weapon with which Beowulf later kills her can harm her_ or indeed Grendel, whose dead body is decapitated with the same weapon.

Furthermore, it is worth drawing attention to a later reference to the trophies of battle. After killing Grendel's mother, Beowulf takes with him both the head of Grendel and the hilt of the sword he has used to remove it:

Ne nom he in pæm wicum, Weder-Geata leod, maðmæhta ma, peh he pær monige geseah, buton pone hafelan ond pa hilt somod since fage. ${ }^{42}$

The two trophies described here are linked by their use somod, 'together'. Both are treasures to Beowulf and the Danes, and the adjective $f a h$ is arguably invoked because of its 
ambiguity — the final verse unit could be referring to the stained and bloodied nature of either the head or the hilt (or both), as well as the crafty adornment of either. I would argue that the verse unit refers to all of these divergent readings and, in doing so, ties together the monstrous body and the prestige object that allows it to be taken apart.

Thus, if we read Grendel and his mother's bodies together, we have substantial evidence for the impenetrability of their skin. While the hero chooses whether or not to put on his armour, these monsters come equipped with an inherent defense that aligns their bodies with the manmade world of constructed objects. What makes these bodies monstrous is precisely their uncanny resemblance to and simultaneous difference from the human body. ${ }^{43}$ In such a way, Grendel and his mother exist liminally, bearing armour that is indivisible from their being. Because constructed objects like armour are symbols of civilization, their monstrous embodiment sets the monsters apart from both the worlds of culture and nature.

\section{STEELy Claws}

Another monster-human resemblance we find in Beowulf relates to the hand-imagery that is prevalent throughout the poem. This imagery is invoked not only in relation to Grendel and his mother, but also to Beowulf, all three characters being attributed with powerful grips. ${ }^{44}$ References to the monsters frequently use terminology applicable to humans, such as folm, hand and finger, withholding details and focusing instead upon the actions that the hands perform. Thus Grendel's arrival at Heorot is marked by his wrenching at the hall-doors:

Duru sona onarn

fyrbendum fæst, $\quad$ sypðan he hire folmum (æt)hran; onbræd pa bealohydig, ða (he ge)bolgen wæs, 
recedes mupan. ${ }^{45}$

This is quickly followed by his seizing of a victim:

$$
\begin{aligned}
& \text { Ne pæt se aglæca } \quad \text { yldan pohte, } \\
& \text { ac he gefeng hraðe forman siðe } \\
& \text { slæpendne rinc, slat unwearnum, } \\
& \text { bat banlocan, blod edrum dranc, } \\
& \text { synsnædum swealh; sona hæfde } \\
& \text { unlyfingendes eal gefeormod, }
\end{aligned}
$$

fet ond folma. ${ }^{46}$

The tearing involved in this passage, marked by the use of slitan, perhaps implies the use of claws, although it could equally refer to the teeth of the monster. Indeed, as we have seen in the previous section, bitan, 'to bite', a verb more associated with the mouth in Modern English, is commonly used of swords, thus aligning manmade blades with teeth.

However, such tearing is later applied to Grendel's arm, which is described in greater detail after his defeat. The monster's downfall is marked by his literal and figurative disarming:

\section{Licsar gebad}

atol æglæca; him on eaxle wearð

syndolh sweotol, seonowe onsprungon,

burston banlocan. ${ }^{47}$

The imagery of banlocan, 'bone-enclosures', underscores the resemblance between Grendel's victim and his own victimization, both passages containing a similar tearing of sinews and veins. $^{48}$

With the removal of Grendel's arm, a clear association between body and object is drawn; the arm becomes a token, allowing the men of the Danes to view the weapon that 
Grendel had raised against them for so long. With this, the poet finally offers a detailed description of the monster's limb:

Pæt wæs tacen sweotol,

$$
\begin{array}{ll}
\text { sypðan hildedeor } & \text { hond alegde, } \\
\text { earm ond eaxle } & \text { - pær wæs eal geador } \\
\text { Grendles grape } & \text { - under geapne hr(of). }{ }^{49}
\end{array}
$$

Grendel's arm appears to be a natural appendage, obviously sharing similarities with a human arm, and yet it also echoes the constructed world of objects, described in a rare simile as possessing nails like steel: ${ }^{50}$

$$
\begin{aligned}
& \text { ofer heanne hrof hand sceawedon, } \\
& \text { feondes fingras; foran æghwylc wæs, } \\
& \text { stede nægla gehwylc style gelicost, } \\
& \text { hæpenes handsporu, hilderinces, } \\
& \text { egl' unheoru. }{ }^{51}
\end{aligned}
$$

The use of style is particularly interesting here, not only because it is generally associated with weapons, ${ }^{52}$ but also because its occurrences in poetry frequently collocate with the verb bitan, discussed above, and the adjectives heard, stið or strong. ${ }^{53}$ Thus, we have further evidence through these collocations that bitan is generally employed in relation to not merely penetration, but the violent striking by a hard weapon - making it all the more certain that Grendel's mother's head is very tough indeed. Furthermore, these collocations are not the only occurrences that emphasize the strength of style; there are two Old English poetic examples of the related adjective, stylen, 'steely', which likewise focus on strength, though of a more negative sort. Solomon and Saturn II contains the only two instances of this adjective in Old English ${ }^{54}$ the first of which describes the steely hell from which the devil comes to tempt humanity, and the second of which (also collocating with heard) depicts the 
metaphorical, steely stone of sin that the angel is unable to dislodge from the sinful person's heart. ${ }^{55}$ The hard metal to which Grendel's nails are likened, thus, carries connotations not only of strength and power, but also of sin and hell.

Because of the lethal weapon that Grendel has attached to his arm, the monster does not need to pick up a sword in order to defeat his enemies. This invalidates Beowulf's assertion that Grendel does not know the arts of war; ${ }^{56}$ whether he does or does not know how to use a sword, fighting without one is entirely practical on the part of Grendel, who already possesses an embodied weapon. Once again, Grendel is placed between the worlds of culture and nature because of his body, while his lack of use of the sword causes his expulsion from the heroic world and its discourse.

When the fight between Beowulf and Grendel is read according to the monstrous embodiment of weaponry and armour, the token of Grendel's arm becomes even more significant. To some, the arm is simply a consolation prize because Grendel escaped with his head, the preferred trophy. ${ }^{57}$ However, because Grendel's arm is a weapon in and of itself, by severing it from his body, Beowulf possesses at once his adversary's weapon and the symbol of his death, since he cannot live long without something so much a part of his body. ${ }^{58}$ Just as regular warriors would be unlikely to survive without their weapons, so too must Grendel die without his arm. As we see elsewhere in the poem, the taking of an opponent's weapons by the winner of a fight is common practice, ${ }^{59}$ which creates an even stronger link between Grendel's actual arm and the regular warrior's sword.

This reading also adds nuance to Grendel's mother's expedition to Heorot. While Hroðgar claims that she comes in order to avenge the feud caused by the killing of her son, ${ }^{60}$ she does not actually harm a human until after her discovery causes her to panic: 
Heo wæs on ofste, wolde ut panon, feore beorgan, pa heo onfunden wæs.

Hraðe heo æpelinga anne hæfde fæste befangen, pa heo to fenne gang. ${ }^{61}$

Indeed, her quiet entrance and subsequent fear upon detection imply that the act of retrieving her son's arm ${ }^{62}$ was as much a motivation as her revenge upon the sleeping warriors. ${ }^{63}$ This runs contrary to Alfred Bammesberger's argument that

Grendel's mother was obviously in an enormous hurry to get away as soon as her presence in Heorot had been discovered, and it is quite unlikely that she should have bothered to snatch Grendel's hand. There was no particular justification for her taking Grendel's hand anyway. Grendel's mother was on a revenge mission. [...] Grendel's hand plays no immediate role whatsoever in this business. ${ }^{64}$

Arguing that the hand Grendel's mother seizes belongs to Æschere rather than Grendel, Bammesberger builds on J. J. Anderson's suggestion that cupe folme is a synecdoche referring to Æschere, the beloved retainer of Hroðgar. ${ }^{65}$

While both of these closely related arguments are interesting, the evidence they provide is not compelling enough to dismiss entirely the possibility that the passage refers to Grendel's arm. Bammesberger's assertion that Grendel's arm cannot be described as bloody because the blood would have dried by the time the arm is removed from its position on the wall $^{66}$ discounts both poetic license and the Beowulf-poet's use of unrealistic blood and body imagery in other passages. ${ }^{67}$ Similarly, his argument that cupe elsewhere refers to excellent or renowned hands rather than murderous ones ${ }^{68}$ does not take into account the fact that the episode is recounting Grendel's mother's view of the situation (Grendel has hands that only a mother could love!) or that the Beowulf-poet frequently employs overlapping diction to link 
the heroes and monsters of the poem. ${ }^{69}$ Furthermore, Anderson's reading notes that 'hand' occasionally stands in for 'person' elsewhere in the poem, while there are no other references to the taking of Grendel's hand. ${ }^{70}$ The fact that Grendel's glof provides a similar point of narrative inconsistency, however, indicates that there is some precedent for seemingly sporadic references to hand-related imagery. Indeed, if we agree with Stanley B. Greenfield's argument that Beowulf's fights against Grendel, his mother and the dragon 'move hierarchically from the literal and emblematic extremities represented by hands and heads to the centers of the body and body politic respectively, the heart and the king, ${ }^{71}$ then the reference to hands in this particular episode is active on more than one level. ${ }^{72}$ It is, therefore, possible that the seizure of the cupe folme provides an intentional ambiguity that serves to link Grendel and Æschere, just as they are later linked through decapitation.

As far as Grendel's actual limb goes, Grendel's mother's reason for reclaiming it is not made explicit. However, the possibility that she wants to place it - at once a part of her son's body and his weapon — at his side for burial is an intriguing one. Indeed, Gale R. OwenCrocker has discussed Grendel's body-parts as trophies taken in order to emphasize his criminality, such exposure being a recognized punishment for severe crimes. ${ }^{73}$ Thus, by attempting to bury him properly, Grendel's mother refutes his guilt. The treasures and weapons, apparently useless to the monsters, collected in the under-water cave indicate an understanding of trophies and a similar importance attributed to crafted objects as held by the humans. This understanding of the use and function of trophies is further revealed when Grendel's mother leaves Æschere's head on the cliff near her home.

And so, it appears that Grendel's hands resemble weapons both in form and in function. As for his mother, here we seem to have a divergent physical feature. Although we can be certain that both monsters possess similarly impenetrable skin, as outlined above, descriptions of Grendel's mother's hands overlap more with Beowulf's than Grendel's. ${ }^{74}$ 
Indeed, Beowulf's powerful clutches are referred to by a metaphorical use of the term clam, 'something that holds or restrains', ${ }^{75}$ twice,${ }^{76}$ as are Grendel's mother's once, in a depiction of her efforts to penetrate the hero's mail-coat:

$$
\begin{aligned}
& \text { Grap pa togeanes, guðrinc gefeng } \\
& \text { atolan clommum; no py ær in gescod } \\
& \text { halan lice; hring utan ymbbearh, } \\
& \text { pæt heo pone fyrdhom ðurhfon ne mihte, } \\
& \text { locene leoðosyrcan lapan fingrum. }{ }^{77}
\end{aligned}
$$

Although the action portrayed here implies an attempt to pierce Beowulf's body with only her hands, the vague description of lapan fingrum makes it impossible to say whether or not these fingers are tipped with steely claws. ${ }^{78}$ Indeed, we can be sure that Beowulf's own hands, which share similar descriptors, are not.

However, we do also know that Grendel's mother possesses a short-sword, since a later passage describes her attacking Beowulf with it:

$$
\begin{aligned}
& \text { Ofsæt pa pone selegyst, ond hyre seax geteah } \\
& \text { brad [ond] brunecg; wolde hire bearn wrecan, } \\
& \text { angan eaferan. }{ }^{79}
\end{aligned}
$$

Arguably, Grendel's mother's use of a weapon functions in the same way as Grendel's lack of use - it sets her outside the heroic world because she is female and therefore excluded from martial combat. ${ }^{80}$ Beowulf's narrator alludes to such an awareness of gender differences when he describes the monstrous woman's war-terror as lesser to that of a man. ${ }^{81}$ Despite this comment, it is notable that Beowulf acts much more cautiously in his fight with Grendel's mother. Rather than replicate his tactics against Grendel, for this battle Beowulf chooses to make use of both armour and weapons. The choice of armour proves a good one, as the poet indicates: 


\section{Him on eaxle læg}

breostnet broden; pæt gebearh feore,

wið ord ond wið ecge ingang forstod. ${ }^{82}$

It is tempting to read the doublet of ord and ecg, against which the corselet protects, as a reference to both Grendel's mother's weapon and her clawed fingers. However, this is fairly speculative, with the alliterating nature of the two nouns naturally pairing them here and elsewhere ${ }^{83}$ Furthermore, scholarship on the semantics of word-pairs notes that the repeated use of such formulaic couplings frequently leads to the loss of the terms' original emphases; thus, 'the individual semantic values of the two members tend to become obscured and merge into one overall meaning, ${ }^{84}$ According to this theory, ord and ecg together could indicate simply 'weapons'. However, in his discussion of 'pledge' word-pairs, Matthias Ammon discusses an example where the 'repeated use of the demonstrative pronoun appears to highlight each of the individual components, putting semantic weight on each of them and thus distinguishing between the concepts' ${ }^{85}$ The Beowulf-passage above includes a similar repetitive intrusion - this time of prepositions - leaving open the possibility that ord and ecg may refer to separate items, such as sword and claws, rather than simply generic 'weapons', after all. ${ }^{86}$

Beowulf's own choice of weapons proves as ineffective as Grendel's mother's ord and ecg, since the sword he has accepted from Unferð similarly fails to penetrate his opponent's body. ${ }^{87}$ The implication here is that Beowulf is not aware that weapons are of no use against the monster's skin. However, as noted above, ${ }^{88}$ the hero and his men have already confirmed Grendel's own impenetrability, indicating perhaps that the two monsters are not considered to share all the same physical traits or perhaps simply that Beowulf is playing it safe when coming up against an unknown foe on her own territory. Alternately, the differing approaches may lie in the divergent motivations of the monsters-while Grendel is depicted 
as a violent evil-doer, his mother has adopted the heroic discourse of vengeance, something that may call for armoured man-to-(wo)man combat. ${ }^{89}$

Regardless of the differences, the interplay of object and body is significant here. Despite their monstrosity, both Grendel and his mother participate in a type of fight or feud that echoes those which take place in the human realm. This only acts to increase their monstrosity, with the use of weapons and body-parts portrayed as weapons acting to both imitate and subvert heroic battle.

\section{CORROSIVE BLOOD}

Beowulf's battle with Grendel's mother leads into a related area of discussion about the monstrous body, this time involving the blood that causes the ancient sword to dissolve. The melting of the giant-wrought sword has occasioned a great deal of scholarly discussion, much of which has involved comparisons with other texts. ${ }^{90}$ However, few have approached this passage in relation to the corrosiveness of Grendel's blood, which seems to be the root cause behind the sword's dissolution. ${ }^{91}$

Blood is frequently invoked in Beowulf, with several references to its heat relating to both monsters and humans. Thus Grendel's flight to the mere is marked by diction similar to that appearing later in relation to Æschere's murder. The first episode reads:

$$
\begin{aligned}
& \text { Đær wæs on blode brim weallende; } \\
& \text { atol yða geswing } \quad \text { eal gemenged } \\
& \text { haton heolfre heorodreore weol. }{ }^{92}
\end{aligned}
$$

While the finding of Æschere's head on the cliffs is followed by the statement:

$$
\begin{aligned}
& \text { Flod blode weol — folc to sægon- } \\
& \text { hatan heolfre. }{ }^{93}
\end{aligned}
$$


The fact that both passages contain the identical formula hatan heolfre, as well as the verb weallan and nouns indicating both blood (blod,-dreor) and water (brim, flod) ties these two episodes firmly together, as does the repetition of 'eo' assonance: heolfre, heorodreore, weol. Outside of Beowulf, we see these terms appearing in poetic collocations, especially in Exodus, where it is Pharaoh's men whose blood stains the water (with similar 'o' assonance linking flod, blode and gewod in line 463b), and in Andreas, where the saint's torture causes his hot blood to flow forth like water. ${ }^{94}$ The heat of Grendel's blood does not, thus, set him apart from humans.

Yet despite this, both Beowulf and the narrator attribute the melting of the giantwrought sword to Grendel's blood:

Pa pæt sweord ongan

æfter heaposwate hildegicelum, wigbil wanian; $\quad$ pæt wæs wundra sum pæt hit eal gemealt ise gelicost, ðonne forstes bend fæder onlæteð, onwindeð wælrapas, $\quad$ se geweald hafað sæla ond mæla; $\quad$ pæt is soð metod. ${ }^{95}$

The extremes of hot and cold combine here to form the image of the melting sword. With such a juxtaposition of a process in nature and the supernatural behaviour of the creature's blood, the poet points out the liminal existence of the monstrous body. Rather than comparing the melting sword to weapons in their molten state, the poet casts his net wider and alludes to the supernatural actions of a supreme being causing the ice to melt and the sea to become water once more. ${ }^{96}$ 
Similar imagery is invoked in Sigemund's dragon-fight: wyrm hat gemealt, ${ }^{97}$ the implication being that the dragon's own heat causes its dead body to be consumed. This melting, furthermore, mirrors the funeral fire of the Finnsburg episode:

\section{Hafelan multon,}

bengeato burston ðonne blod ætspranc,

laðbite lices; lig ealle forswealg. ${ }^{98}$

In both of these cases, melting is couched in terms of heat similar to that of Grendel's blood. These links between heat and melting have led to the assumption that in this instance it is the heat of Grendel's blood alone that causes the melting of the sword. However, both of the other instances involve fire-whether that of the dragon or the funeral pyre - while Grendel, although figuratively connected to fire, ${ }^{99}$ is not associated with actual flames. He is, rather, linked to poison, as is evident from the poet's assertion immediately following the swordmelting passage:

sweord ær gemealt,

forbarn brodenmæl; $\quad$ wæs pæt blod to pæs hat, ættren ellorgæst $\quad$ se pær inne swealt. ${ }^{100}$

The implication here is that Grendel's blood is poisonous, and it is the heat caused by this poison that melts the blade.

Poison and heat are conflated elsewhere in Beowulf, as we see from the hero's own death, which is described through diction similar to that of the passages above:

Đa sio wund ongon,

pe him se eorðdraca ær geworhte, swelan ond swellan; he pæt sona onfand, pæt him on breostum bealonið(e) weoll attor on innan. ${ }^{101}$ 
The use of weallan and attor is coupled with swelan and swellan, verbs indicating the heat felt in the wound, with the implication that poison can produce heat of the sort that can destroy bodies. From this and the examples discussed above, we can see, then, that poison, heat and the welling of blood are commonly collocated in the poem. While the heat and welling are closely linked to the observation of the workings of the human body, for this poisonous element we must look elsewhere. ${ }^{102}$

Again, close reading of the poem can point us in the right direction. Before Beowulf departs Heorot to track down Grendel's mother, Unferð gives him his sword, which is described in the following terms:

$$
\begin{aligned}
& \text { wæs pæm hæftmece Hrunting nama; } \\
& \text { pæt wæs an foran ealdgestreona; } \\
& \text { ecg wæs iren, atertanum fah, } \\
& \text { ahyrded heaposwate. }^{103}
\end{aligned}
$$

Although it is difficult to pin down the exact meaning of atertanum fah, a parallel is clearly being drawn between poison and the sword-blade. The phrase has been interpreted as an attempt to enhance the efficacy of the weapon's edge through the use of runes of the sort we see in Sigrdrífomál and possibly on several archaeological finds. ${ }^{104}$ Alternately, some scholars read the verse unit as a reference to the design produced by pattern-welding. ${ }^{105}$ Hilda Roderick Ellis Davidson gives a good overview of these and other possible readings, including both the etching of a blade by chemicals and as a kenning for serpents. ${ }^{106}$ However, she dismisses the idea that it may refer to the poisoning of weapons out of hand, despite the Old Norse, continental and Old English prose analogues she discusses, as well as several Old English poetic parallels, which will be discussed below. ${ }^{107}$ Her reasoning for this is that it would have been difficult to poison a weapon without endangering the bearer, further arguing that these 'are the methods of assassins and not of warriors. There are two adequate reasons 
for associating weapons and poison: one is the use of acid in the making of the sword, and the second is the continued association in poetry between swords and serpents'. ${ }^{108}$ Davidson also defers to an article by F. Genzmer, which maintains that snake venom was seen to bestow additional power, whether when added to food or the molten blade. ${ }^{109}$ After a very brief survey of only two Old Norse literary examples and their adaptation in Saxo Grammaticus' Gesta Danorum — indeed, he does not allude to this example from Beowulf at all, nor to any non-literary/legendary evidence - Genzmer concludes that the Germanic peoples did not cover finished blades with poison.

This dismissal is perhaps overly hasty, especially considering that the legendary nature of the material allows for the occurrence of a great deal that is not possible in everyday life. The Beowulf-poet may well have wished to invoke the image of a poisoned weapon in order to heighten the danger of Beowulf's entrance into Grendel's mother's home- - a fitting context to be linked to assassination, I might add, since Beowulf is now an intruder rather than a defender. Furthermore, this sword belongs to Unferð, a character with a problematic role in the poem. ${ }^{110}$ It is therefore possible that this arguably less heroic warrior could own a poisoned blade: if we read him as attempting to help Beowulf, he may have lent the sword because of its additional power; if we read him as antagonistic toward Beowulf, then Davidson's discussion of the dangers of fighting with a poisoned blade is made all the more pertinent.

Furthermore, there is a great deal of poetic precedence for the relating of poison and weapons in Old English. Poisoned weapons are scattered throughout the written record, with two examples in The Battle of Maldon, the first of which occurs during Byrhtnoð's speech to the Viking messenger:

$$
\begin{aligned}
& \text { Hi willað eow to gafole garas syllan, } \\
& \text { ættrynne ord and ealde swurd, }
\end{aligned}
$$


pa heregeatu pe eow æt hilde ne deah. ${ }^{111}$

The second instance refers to Byrhtnoð's death:

he wæs on breostum wund

purh ða hringlocan; him æt heortan stod

ætterne ord. ${ }^{112}$

The editors of Klaeber Four consider these phrases to be 'purely metaphorical' in nature, referring to the deadliness of the weapons. ${ }^{113}$ The $D O E$, on the other hand, defines cettren here as 'of spikes, spear-points, weapons etc.: tipped with poison, deadly'. ${ }^{114}$ Although the figurative reading of 'deadly' is an option, the $D O E$ 's editors also leave open the possibility that the weapons may be literally poisoned.

A further example occurs in Andreas, when the devil urges the crowd of Mermedonians to kill the saint:

Lætað gares ord, earh ættre gemæl, in gedufan in fæges ferð. ${ }^{115}$

The DOE includes this instance under the sense, 'poison, poisonous substance (administered to someone in food or a potion, smeared on a weapon, etc.) .116 This definition makes it clear that the $D O E$ editors favour the reading of these lines as a reference to a completed blade that is coated with poison, rather than as an allusion to the chemicals used in the etching process of sword-manufacturing, as Davidson prefers. ${ }^{117}$ Unfortunately, the ambiguity of gemoelan's senses, 'to mark' or 'to stain', makes it difficult to say either way. However, there is also glossarial evidence where gemcelan and attor are once again paired, together glossing lita veneno, 'smeared with poison'. ${ }^{118}$ The Latin verb linere carries the sense of spreading or rubbing a substance over something, rather than infusing one with the other. ${ }^{119}$ As the $D O E$ editors note, this gloss likely refers to a line from Aldhelm's Carmen de virginitate, which 
describes personified Avarice marching through town, arma cruenta ferens et spicula lita veneno. ${ }^{120}$ Furthermore, the diabolic nature of the Mermedonians, who are shown to use potions at the beginning of the poem, ${ }^{121}$ may imply the use of poison on the blades with which the demon wants Andreas murdered.

The relationship between demon and poison that Andreas depicts may also speak to another, less physical connotation. Indeed, there are two further examples of poisoned weapons that tend to be left out of discussions of the Beowulf-passage, possibly because the weapons involved are metaphorical. The first occurs in Cynewulf's Christ II, where sin is depicted as a poisoned weapon that attacks the soul:

$$
\begin{aligned}
& \text { Forpon we fæste sculon wið pam færscyte } \\
& \text { symle wærlice wearde healdan, } \\
& \text { py læs se attres ord in gebuge, } \\
& \text { biter bordgelac, under banlocan, } \\
& \text { feonda færsearo. } \quad \text { Pæt bið frecne wund, } \\
& \text { blatast benna. }{ }^{122}
\end{aligned}
$$

Ord is once again coupled with poison, although here we have attor in the genitive case, as opposed to the adjective, cettren. The DOE takes this phrase to be a 'point of poison, poisonous point' (fig., of the arrows of the devil)' ${ }^{123}$ While this instance is certainly a metaphor - this time for sin's pervasiveness rather than the deadliness of swords - it seems to act differently from the above instances in The Battle of Maldon and Andreas. The weapon here does indeed carry poison within it, and, when it enters into the human soul, the poison spreads not unlike the dragon's actual venom does in Beowulf's final battle. ${ }^{124}$

A related example from Juliana, also by Cynewulf, involves the demon that is constrained by the saint confessing his evils. This long list includes the blinding of humans upon whom he inflicts evil thoughts: 
Oft ic syne ofteah,

$$
\begin{aligned}
& \text { ablende bealoponcum beorna unrim } \\
& \text { monna cynnes misthelme forbrægd } \\
& \text { purh attres ord eagna leoman } \\
& \text { sweartum scurum. }{ }^{125}
\end{aligned}
$$

The implication here is that the removal of sight is figurative - the afflicted humans are spiritually blinded and caused to sin by the poisonous points of the devil. However, in addition to the mental afflictions, the list of the demon's crimes includes many physical ones, such as drowning or causing victims to bleed to death, so it is possible that the poisoned weapons cause both figurative and literal loss of sight, marking both the soul and the body. Indeed, as Jagger notes, 'Despite their very different conceptualisations of the body [...], Cynewulf and the Beowulf-poet both present a worldview that is equally and persistently informed by a dominant awareness of the corporeal'. ${ }^{126}$

The above examples from both heroic and religious texts demonstrate an Old English poetic tradition — with a range of differing metaphorical associations — that links poison with weapons. As a recognized trope in Old English poetry, it is possible that the Beowulf-poet, who clearly depicts poisonous wounds elsewhere, could have invoked it, either literally or figuratively, in order to enhance the excitement of an already spectacular scene. Notably, Beowulf's poisoned wound is also depicted in terms of burning in the blood; for this poisonous corrosiveness to be transferred, then, from weapon to monster's blood is an easy transition. Like the 'poisonous' objects used in battle, Grendel's blood becomes poisonous in itself, corrupting the blade rather than allowing the blade to corrupt the opponent's body.

As to whether Grendel's mother shares this monstrous characteristic with her son, the textual evidence indicates otherwise. Her decapitation - the same wound Grendel's dead body will later receive-is described in the following passage: 


$$
\begin{aligned}
& \text { He gefeng pa fetelhilt, freca Scyldinga } \\
& \text { hreoh ond heorogrim, hringmæl gebrægd, } \\
& \text { aldres orwena, yrringa sloh, } \\
& \text { pæt hire wið halse heard grapode, } \\
& \text { banhringas bræc; bil eal ðurhwod } \\
& \text { fægne flæschoman, } \quad \text { heo on flet gecrong; } \\
& \text { sweord wæs swatig, } \quad \text { secg weorce gefeh. }{ }^{127}
\end{aligned}
$$

The sword is clearly depicted as being bloody, and yet Beowulf is still able to use it to remove the head of Grendel, only after which it dissolves. If Grendel's mother's blood were as corrosive as that of her son, then logically the blade would need to melt directly after coming into contact with her. ${ }^{128}$ However, belabouring logic does a disservice to the legendary nature of the text and to the possible metaphorical connotations of this scene in particular. The fact that the melting of the sword is linked to God loosing the fetters of frost suggests divine intervention, as well as the movement from one metaphorical season - that of Grendel's family's threat against Heorot— to another, more bountiful one. ${ }^{129}$

Hence, while Grendel's mother possesses some physical traits in common with her son, the two monsters are not wholly identical. ${ }^{130}$ Yet an examination of both characters' bodies has led to interesting correspondences between the realms of monster and human, nature and culture. It is clear from a survey of the skin, hands and blood of Grendel, and to a lesser extent his mother, that Beowulf's opponents are equipped with bodies shaped in the image of both humans and manmade objects. Furthermore, just as Cohen refers to the monster's presence as 'a rebuke to boundary and enclosure', ${ }^{131}$ so too are the components that make up the monstrous body, blurring the limits between body and objects of war in a way that threatens the civilizing impulse of human construction. It is, thus, because of the 
boundaries transgressed by their very bodies that Grendel and his mother can exist neither as part of the natural world nor the cultural world. Rather, they stand forever between and outside of both. ${ }^{132}$

\footnotetext{
${ }^{1}$ For discussions of construction in Old English poetry - many of which focus on buildings or larger-scale objects—see R. Wehlau, 'The Riddle of Creation': Metaphor Structures in
} Old English Poetry, Stud. in the Humanities 24 (New York, 1997); E. R. Anderson, 'The Uncarpentered World of Old English Poetry', ASE 20 (1991), 65-80; L. A. Garner, Structuring Spaces: Oral Poetics and Architecture in Early Medieval England (Notre Dame, IN, 2011); and M. Cavell, 'Representations of Weaving and Binding in Old English Poetry' (unpubl. PhD dissertation, Univ. of Cambridge, 2012), pp. 12-62.

${ }^{2}$ Scholarship on weapons and armour in Old English literature is vast. For a general survey, see in particular H. R. E. Davidson, The Sword in Anglo-Saxon England: its Archaeology and Literature (Oxford, 1962); G. Clark, 'Beowulf's Armor', ELH, 32.4 (1965), 409-441; and C. Brady, "Weapons" in Beowulf: an Analysis of the Nominal Compounds and an Evaluation of the Poet's Use of Them', ASE 8 (1979), 79-141.

${ }^{3}$ Borrowing the terms of Claude Lévi-Strauss's anthropological study of the nature/culture binary, Le Cru et le Cuit (Paris, 1964), John D. Niles similarly discusses riddle-objects and their usefulness to humans: 'What the riddles prize above all is the way things turn to the welfare of humankind. Rarely is the 'raw' stuff of nature introduced (a deer's antlers, an ox's hide) without its being brought into relation to the 'cooked' elements of culture (a pair of inkwells, a set of leather goods). The riddles thus domesticate the elements of nature and turn them to human use'. See Old English Enigmatic Poems and the Play of the Texts, Stud. in the Early Middle Ages 13 (Turnhout, 2006), p. 54. 
${ }^{4}$ Thus, isen/iren, 'iron', is synonymous with 'sword', while the only poetic instance of pure gold occurs in relation to the smelting process. See Elene 1308b-12a. For weapon- and armour-riddles, see Riddles 5, 17, 20, 23, 35, 71 and 73 (according to Krapp and Dobbie's numbering system; full citation for The Exeter Book below, n. 17). Note, however, that Riddle 83 likely refers to 'ore'.

${ }^{5}$ See T. Cuthbert, 'The Narrative Function of Beowulf's Swords', JEGP 59 (1960), 13-20.

6 'Beowulf' and the Appositive Style (Knoxville, 1985), p. 71. This builds on Clark's discussion of weapons and armour in specific: 'Arms and armor in Beowulf are human artifacts, instances of man's creative power and of his control over nature'. See 'Beowulf's Armor', 409.

${ }^{7}$ For a discussion of the 'knot-body' in Beowulf, see R. P. Tripp, Jr, 'Language, Archaic Symbolism, and the Poetic Structure of Beowulf', Hiroshima Stud. in Eng. Lang. and Lit. 19 (1972), 1-21; and Cavell, 'Weaving and Binding', pp. 133-42.

8 'bone-house'. See The Dictionary of Old English: A-G Online, ed. A. diPaolo Healey, D. Haines, J. Holland, D. McDougall and I. McDougall, with P. Thompson and N. Speirs (Toronto, 2007), s.v. (hereafter, DOE).

9 'bone-hall'. See $D O E$, s.v.

${ }^{10}$ See 'Bodies, Buildings, and Boundaries: Metaphors of Liminality in Old English and Old Norse Literature', Essays in Med. Stud.: Proc. of the Illinois Med. Assoc. 11 (1994), 43-50.

${ }^{11}$ See J. Neville, Representations of the Natural World in Old English Poetry, CSASE 27 (Cambridge, 1999).

${ }^{12}$ Neville notes that it is impossible to distinguish between what modern readers would consider 'natural' and 'supernatural' phenomena; thus 'bloodthirsty, man-shaped creatures', such as Grendel and his mother, pose an equal threat to humans as wolves and other beasts do. See Representations of the Natural World, p. 2. However, in a later article, she argues for 
distinct differences between animal threats and humanoid monsters because of the latter's similarity to and subversion of humanity. See 'Monsters and Criminals: Defining Humanity in Old English Poetry', in Monsters and the Monstrous in Medieval Northwest Europe, ed. K. E. Olsen and L. A. J. R. Houwen, Mediaevalia Groningana 3 (Leuven and Paris, 2001), 10322.

13 'Monster Culture (Seven Theses)', in Monster Theory: Reading Culture, ed. J. J. Cohen (Minneapolis, 1996), pp. 3-25, at 6.

${ }^{14}$ Neville, 'Monsters and Criminals', 112 and 117.

${ }^{15}$ Holly Jagger also discusses overlapping imagery of armour and the body in her unpublished dissertation: 'Armour $[. .$.$] metonymically functions as the material embodiment$ of a warrior's identity. But the Beowulf-poet portrays the roles of bodies and weapons as interchangeable. Just as weapons are personified so too people are transformed metaphorically into the metal trappings that adorn them'. 'Body, Text and Self in Old English Verse: A Study of 'Beowulfian' and 'Cynewulfian' Rhetoric' (unpubl. PhD dissertation, Univ. of Toronto, 2002), pp. 66-7.

${ }^{16}$ References to Grendel as a dark and shadowy creature suggest that he functions as a symbol of the terrible unknown: 'The monster Grendel provokes a sensation of horror precisely because it lies outside perceived cultural or scientific categories and is, therefore, frighteningly unfamiliar'. M. Lapidge, 'Beowulf and the Psychology of Terror', in Heroic Poetry in the Anglo-Saxon Period: Studies in Honor of Jess B. Bessinger Jr., ed. H. Damico and J. Leyerle (Kalamazoo, 1993), pp. 373-402, at 393.

${ }^{17}$ Klaeber's Beowulf, ed. R. D. Fulk, R. E. Bjork and J. D. Niles, 4th ed. (Toronto, 2008), line 681a: 'he does not know of those good things'. All references to Beowulf are to this edition (hereafter, Klaeber Four). All references to The Junius Manuscript, The Vercelli Book 
and The Exeter Book are to the editions by E. van Kirk Dobbie and G. P. Krapp, ASPR 1-3 (New York, 1931, 1932 and 1936). All translations are my own.

${ }^{18}$ Hence the editors of Klaeber Four point to the following paet-clause, in which fighting with a sword and shield is described, for an explanation of what goda indicates. See p. 157.

${ }^{19}$ Lines 798-803: 'They did not know, when they endured the conflict, the brave-minded battle-warriors, and intended to hew on each side, to seek the soul, that no battle-sword, the best of irons anywhere throughout the earth, could touch the criminal ravager'.

${ }^{20}$ Although they do, of course, later agree that Grendel could not be touched by swords:

Æghwylc gecwæð

pæt him heardra nan hrinan wolde

iren ærgod pæt ðæs ahlæcan

blodge beadufolme onberan wolde.

Lines 987b-90: 'everyone said that no harder iron, good of old, could touch him, so that it would injure the bloody battle-hand of that adversary'.

${ }^{21}$ Lines 804-5a: 'but he had forsworn victory-weapons, every edge'.

${ }^{22}$ Sense 2 . The square brackets are the dictionary's own.

${ }^{23}$ See p. 163.

${ }^{24}$ See, for example, where he is linked to the term -sceapa, 'criminal' or 'enemy' at lines 274b, 479a, 707a, 712a, 737b, 766a, 801b and 2093b, and to the term foehðo, 'feud' at lines 134b-7, 153a, 590-601, 1333b-44, 1380-2 and 2480a.

${ }^{25}$ Grendel is associated with the devil and demons in lines 101a, 143b, 164b, 279b, 439a, 636a, 698b, 725b, 748a, 756a, 808a, 962a, 970a, 984a, 1273b, 1276a, 1669a, 1680a and 2088a. He is linked to the race of Cain in lines 107a and 1260-6, a group that includes the eoten, 'giant', which is equally applied to Grendel at line 761a. For a description of Cain's feud with God, see lines 102-14. For discussions of the devil's oath-breaking and feud, see P. 
Dendle, Satan Unbound: the Devil in Old English Narrative Literature (Toronto, 2001); R.

Woolf, ‘The Devil in Old English Poetry', RES 4 (1953), 1-12.

${ }^{26}$ See E. D. Laborde, 'Grendel's Glove and his Immunity from Weapons', MLR 18 (1923), 202-4, at 202; W. W. Skeat, 'On the Signification of the Monster Grendel in the Poem of Beowulf; with a Discussion of Lines 2076-2100', Jnl of Philol. 15.29 (1886), 120-31.

${ }^{27}$ A. M. Pfrenger, 'Grendel's Glof: Beowulf line 2085 Reconsidered', $P Q 87.3$ (Summer 2008), 209-35, at 224-6.

${ }^{28}$ Line 2086b: 'fast with cunning bonds'.

${ }^{29}$ Lines 2087-8: 'entirely adorned with skillful work, with the devil's arts and with dragons' skins'.

${ }^{30}$ Pfrenger, 'Grendel's Glof', 224.

${ }^{31}$ Line 2085b: 'A glove hung'.

${ }^{32}$ The other instances of this verb in Beowulf occur at lines 1363a (describing tree-branches), $1662 \mathrm{~b}$ (describing the giant-wrought sword on the wall of Grendel's mother's cave) and $2447 b$ (describing a hanged man). For further discussion of the Grendel's glof passage, see Cavell, 'Weaving and Binding', pp. 56-61.

${ }^{33}$ See the $D O E$ entries for gyrwan (senses 2.-2.b.i.b.) and gegyrwan (senses 2.-2.b.).

${ }^{34}$ For more on Beowulf's use of armour in this fight, see R. Trilling, 'Beyond Abjection: The Problem with Grendel's Mother Again', Parergon 24.1 (2007), 1-20.

${ }^{35}$ Lines 1519b-25a: 'he gave a powerful thrust with his battle-sword; his hand did not hold back the blow, so that the ring-ornament sang a greedy war-song on her head. Then the guest discovered that the battle-light would not bite, injure the life, but the edge failed the leader in his need'.

${ }^{36}$ Line 323a: '[it] sang in the war-gear'. 
${ }^{37}$ Lines 1448-54: 'but the shining helmet protected his head, that which had to stir up the seabeds, seek the surging-water, adorned with treasure, surrounded with noble chains, as a weapon-smith wrought it in days of old, bound it with wonders, set it with boar-likenesses, so that afterward no sword or battle-blades would be able to bite it'.

${ }^{38}$ See sense 2.

${ }^{39}$ See line $9 \mathrm{a}$.

${ }^{40}$ See line 23a.

${ }^{41}$ See line $18 b$.

${ }^{42}$ Lines 1612-15a: 'He did not take from that place, the leader of the Weder-Geats, more of valuable objects, although he saw much there, except the head and the hilt together, adorned/stained with treasure'.

${ }^{43}$ See Cohen, 'Monster Culture', p. 11.

${ }^{44}$ See M. M. Carens, 'Handscóh and Grendel: the Motif of the Hand in Beowulf', in Aeolian Harps: Essays in Literature in Honor of Maurice Browning Cramer, ed. D. G. Fricke and D. C. Fricke (Bowling Green, 1976), pp. 39-55; J. Rosier, 'The Uses of Association: Hands and Feasts in Beowulf', PMLA 78 (1963), 8-14; S. Weil, 'Grace under Pressure: 'Hand-Words,' Wyrd and Free Will in Beowulf', Pacific Coast Philology 24 (1989), 94-104; and Jagger, 'Body, Text and Self', pp. 117-25.

${ }^{45}$ Lines 721b-4a: 'The door sprang open at once, fast in fire-forged bonds, after he touched it with his hands; the angry-minded one wrenched it open, when he was enraged, the mouth of the hall'.

${ }^{46}$ Lines 739-45a: 'The adversary did not then think to delay, but at the first opportunity he quickly grasped a sleeping warrior, tore greedily, bit the bone-enclosures, drank blood from the veins, swallowed huge pieces; at once he had devoured all of the un-living one, feet and hands'. 
${ }^{47}$ Lines $815 \mathrm{~b}-18 \mathrm{a}$ : 'The fierce adversary endured a bodily wound; on his shoulder there was a clear, gaping wound, his sinews sprang apart, the bone-enclosures burst'.

${ }^{48}$ For more on banlocan and this passage in particular, see Cavell, 'Weaving and Binding', pp. 137-42.

${ }^{49}$ Lines 833b-6: 'That was a clear token, after the battle-brave one laid down the hand, arm and shoulder — there was Grendel's grip all together — under the vaulted roof'.

${ }^{50}$ Donald K. Fry proposes a link between references to Grendel's ncegla and Beowulf's sword Noegling, perhaps suggested by the bursting of both Grendel's fingers at line $760 \mathrm{~b}$ and the sword at line 2680b. See 'Wið earm gescet and Beowulf’s Hammerlock', MP 67 (1970), 364-66, at 365, n. 10.

${ }^{51}$ Lines 983-7a: 'they examined the hand over the vaulted roof, the fiend's fingers; in the front, each of the places of nails of the heathen one, the battle-warrior's hand-spur, was most like steel, horrible [and] awful'. For discussion of the meaning of line 983a, see R. H. Bremmer, Jr., 'Grendel's Arm and the Law', in Studies in English Language and Literature: “Doubt Wisely”, ed. M. J. Toswell and E. M. Tyler (London, 1996), pp. 121-32. Jagger also discusses overlapping diction that aligns weapons and body-parts here: 'Body-parts are presented, then, as veritable weapons, active or inactive, just as weapons are conversely personified as the limbs of the men who wield them [...]. Just as Nægling has hand-like features, so Grendel's “principal weapon”, his “battle-hand” (beadufolme, 990a), is itself depicted as a weapon, bloodied after battle, with steel fingers and talons like knives (Beo 983-90)'. 'Body, Text and Self', pp. 119-20.

${ }^{52}$ See also line 1533a, where Unferð's sword, which fails to penetrate Grendel's mother's head is described as stið ond stylecg, 'strong and steel-edged'. Examples outside of Beowulf occur in Riddle 40, lines 78-9, where Creation is depicted as harder than the flint that strikes sparks from steel, and in Riddle 93, lines 18b-19a, where the swords that bite the inkhorn are 
attributed with steel blades. Likewise, Solomon and Saturn II contains a reference to old age, which surpasses steel and bites iron. See The Old English Dialogues of Solomon and Saturn, ed. D. Anlezark, AS Texts 7 (Cambridge, 2009), lines 122b-3.

${ }^{53}$ Of the instances noted above, Riddle 93 includes a collocation of style, bitan, heard and stið; Solomon and Saturn II includes a collocation of style and bitan; Riddle 40 includes a collocation of style, heard and strong; and the description of Unferð's sword includes a collocation of style and stið, which closely follows the reference to bitan in line 1523b; see above, pp. 7-8.

${ }^{54}$ Although note that Layamon's Brut also mentions a sword that is stelene at line 7634 . See Layamon, Brut, or, Hystoria Brutonum, ed. and trans. W. R. J. Barron and S. C. Weinberg (Harlow, 1995).

${ }^{55}$ See Dialogues of Solomon and Saturn, ed. Anlezark, lines 311 and 327a.

${ }^{56}$ See above, p. 3.

${ }^{57}$ Cohen touches on this in Of Giants: Sex, Monsters, and the Middle Ages, Med. Cultures Series (Minneapolis, 1999), at p. 64. For the legal context of dismemberment, see also Bremmer, 'Grendel's Arm and the Law'; K. O'Brien O'Keeffe, 'Body and Law in Late Anglo-Saxon England', ASE 27 (1998), 209-32; and G. R. Owen-Crocker, 'Horror in Beowulf: Mutilation, Decapitation, and Unburied Dead', in Early Medieval Texts and Interpretations: Studies Presented to Donald G. Scragg, ed. E. Treharne and S. Rosser (Tempe, AZ, 2002), pp. 81-100.

${ }^{58}$ See Tripp, 'Language, Archaic Symbolism', 19-20.

${ }^{59}$ See lines 2032-56, in which an old Heaðobeard warrior incites a young retainer by pointing out that one of the Danes is wielding his dead father's sword. See also E. Oakeshott, Records of the Medieval Sword (Woodbridge, 1991), p. 2; and Clark, 'Beowulf's Armor', 411. ${ }^{60}$ See lines $1333 b-7 a$. 
${ }^{61}$ Lines 1292-6: 'She was in haste, wanted out from there, to protect her life, when she was discovered. Quickly she had seized one of the noblemen firmly, when she went to the fen'. 62 heo under heolfre genam

cupe folme

Lines 1302b-3a: 'she seized the well-known hand under the gore'.

63 ond his modor pa gyt

gifre ond galgmod gegan wolde sorhfulne sið, sunu deoð wrecan.

Lines 1276b-8: 'and his mother then still longing and gallows-minded wanted to go on a sorrowful journey, to avenge her son's death'. Note, however, that the verse unit sunu deoð wrecan is emended from sunu peod wrecan. Klaeber Four, p. 45. For an alternate reading that does not require emendation, see G. H. Brown, 'Beowulf 1278b: "sunu peod wrecan”, MP 72 (1974), 172-4. A second passage alluding to Grendel's mother's vengeance in terms of a blood feud — this time from Beowulf's point of view—occurs at lines 1333b-44.

64 'Old English Cupe Folme in Beowulf, Line 1303A', Neophilologus 89 (2005), 625-7, at 626.

65 'The cupe folme in Beowulf', Neophilologus 67 (1983), 126-30.

66 'Old English Cupe Folme’, 627.

${ }^{67}$ See below, n. 98 .

68 'Old English Cupe Folme’, 626.

${ }^{69}$ Note, for example, the famous case of agloeca (fierce adversary), which is applied to Grendel, his mother (as aglaecwif), the dragon and Beowulf throughout the poem. See lines 425a, 556a, 733a, 739a, 893a, 1000b, 1259a, 1269a, 1512a, 2520a, 2534a, 2557a, 2592a and 2905a.

70 'cupe folme in Beowulf', 127 and 126, respectively. 
71 'The Extremities of the Beowulfian Body Politic', in Saints, Scholars and Heroes: Studies in Medieval Culture in Honour of Charles W. Jones, ed. M. H. King and W. M. Stevens, 2 vols (Collegeville, MN, 1979), I, 1-14, at 2.

${ }^{72}$ Indeed, Greenfield argues that the once-strong hand that now lies still in line $1343 \mathrm{~b}$ refers to Grendel's arm, Æschere's and Hroðgar's simultaneously. Ibid. p. 6.

73 'Horror in Beowulf', pp. 92-4. Another possibility for his mutilation suggested by Old Norse analogues is the fear that he will return from the dead as a zombie-like draugr or haugbúi. See p. 93, as well as Klaeber Four, p. 210.

${ }^{74}$ For a discussion of the human aspects of Grendel's mother and her dehumanization in scholarly criticism and translations of the poem, see C. Alfano, 'The Issue of Feminine Monstrosity: a Reevaluation of Grendel's Mother', Comitatus 23 (1992), 1-16. Note, however, that Alfano does not discuss the impenetrable skin clearly attributed to Grendel's mother, a feature she shares with her son. Perhaps more nuanced is Niles' analysis: 'Her almost civilized dwelling and her use of the seax locate her nearer the human than the nonhuman end of the spectrum between mankind and the beasts, but we are left guessing as to her exact nature'. Beowulf: The Poem and its Tradition (Cambridge, MA, 1983), p. 10. ${ }^{75}$ DOE, sense 1. In this case, 1.b.: 'grip', 'grasp' or plural 'clutches'.

76 Ic hine hrædlice heardan clammum on wælbedde wripan pohte, pæt he for mundgripe minum scolde licgean lifbysig, butan his lic swice.

Lines 963-6: 'I quickly thought to bind him with hard clutches on the slaughter-bed, so that he, because of my hand-grip, should lie struggling for his life, unless his body should escape'.

Heo pa fæhðe wræc

pe pu gystran niht Grendel cwealdest 
purh hæstne had heardum clammum,

forpan he to lange leode mine

wanode ond wyrde.

Lines 1333b-7a: 'She avenged that feud when you yesterday night killed Grendel in a violent manner with hard clutches because he had diminished and destroyed my people for too long'. ${ }^{77}$ Lines 1501-5: 'She reached then against him, seized the battle-warrior with terrible grips; none the sooner could she injure the unharmed body within; a ring protected from outside, so that she might not pierce the war-garment, the interlocked mail-shirt, with hateful fingers'. ${ }^{78}$ Although Niles assumes they must be: 'for we are told that when she seizes Beowulf only his byrnie prevents him from being torn to shreds (1501-05)'. Beowulf: The Poem and its Tradition, p. 10. This is not, strictly speaking, true to the text, which refers only to her attempts to pierce the hero's body, rather than the sort of animalistic tearing that Niles portrays.

${ }^{79}$ Lines 1545-7a: 'Then she set upon the hall-guest and withdrew her short-sword, broad and bright-edged; she wanted to avenge her son, her only child'. For a discussion of the translation of line 1545a, see F. C. Robinson, 'Did Grendel's Mother Sit on Beowulf?', in From Anglo-Saxon to Early Middle English: Studies Presented to E. G. Stanley, ed. M.

Godden, D. Gray and T. Hoad (Oxford, 1994), pp. 1-7.

${ }^{80}$ For more on gender and the role of women in Beowulf and other Old English poetry, see A. Hennessey Olsen, 'Gender Roles', in A Beowulf Handbook, ed. R. E. Bjork and J. D. Niles (Exeter, 1997), pp. 311-24; C. J. Clover, 'Regardless of Sex: Men, Women, and Power in Early Northern Europe', Representations 44 (October 1993), 1-28; M. J. Enright, Lady with a Mead Cup: Ritual, Prophecy and Lordship in the European Warband from La Tène to the Viking Age (Dublin, 1996); E. Tuttle Hansen, 'Women in Old English Poetry Reconsidered', Michigan Academician: Papers of the Michigan Acad. of Science, Arts, and Letters 9 (1976), 
109-17; J. Hill, 'Pæt Wæs Geomuru Ides! A Female Stereotype Examined', in New Readings on Women in Old English Literature, ed. H. Damico and A. Hennessey Olsen (Bloomington, 1990), pp. 235-47; S. Horner, The Discourse of Enclosure: Representing Women in Old English Literature (Albany, NY, 2001); S. S. Klein, Ruling Women: Queenship and Gender in Anglo-Saxon Literature (Notre Dame, 2006); G. R. Overing, Language, Sign and Gender in Beowulf (Carbondale, 1990); D. Carr Porter, 'The Social Centrality of Women in Beowulf', Heroic Age 5 (July 2001), n.pag.; L. M. Sklute, 'Freoðuwebbe in Old English Poetry', NM 71 (1970), 534-41; and Cavell, 'Weaving and Binding', p. 197-206.

${ }^{81}$ See lines $1282 b-7$.

${ }^{82}$ Lines 1547b-9: 'On his shoulder lay a braided breast-net; that protected his life, it prevented entry against point and against edge'.

${ }^{83}$ See also line 202 of Maxims I and 60a of The Battle of Maldon.

${ }^{84}$ I. Koskenniemi, Repetitive Word Pairs in Old and Early Middle English Prose (Turku, 1968), p. 23. See also M. Ammon, 'Pledges and Agreements in Old English: a Semantic Field Study' (unpubl. PhD dissertation, Univ. of Cambridge, 2010), p. 64.

85 'Pledges and Agreements', p. 63. In a later paper, 'The Semantics of Word-pairs in Old English', Dept of ASNC Research Seminar (Cambridge, 23 March 2012), Ammon suggested that the unnecessary repetition of pronouns and prepositions sometimes indicates a transitional phase before the loss of individual sense.

${ }^{86}$ Admittedly, Ammon is more concerned with legal prose; however, the metre of this verse unit makes the second instance of wið unnecessary, implying that its use does not simply stem from poetics.

${ }^{87}$ J. L. Rosier argues that Unferð is a treacherous figure, implying that the sword's failure was intentional and maintaining that Beowulf blames Hrunting for its inability to penetrate Grendel's mother. See 'Design for Treachery: the Unferth Intrigue', PMLA 77.1 (Mar. 1962), 
1-7, at 5-6. In 'Beowulf's Armor', at 227-8, Clark similarly reads the character of both Unferð and his sword in this light, rejecting the objections of N. Eliason ('The Pyle and Scop in Beowulf', Speculum 38.2 (April, 1963), 267-84) as misleading and simplistic. It is possible, then, that had Beowulf used his own sword, he would have been more successful. See also below, n. 110 .

${ }^{88}$ See above, n. 19.

${ }^{89}$ Indeed, Greenfield links the different combat methods to the separate focuses of each battle: hands for Grendel (thane versus anti-thane); sword and head for Grendel's mother (avenger versus mock avenger); and shield and heart for the dragon (king versus anti-king). 'Extremities of the Beowulfian Body Politic', pp. 9-12.

${ }^{90}$ For example, this scene has been read in relation to the Irish tales about Cú Chulainn's battle-fury (see M. Puhvel, 'The Melting of the Giant-Wrought Sword in Beowulf', ELN 7 (1969), 81-4), as well as classical texts (see F. H. Whitman, 'Corrosive Blood in Beowulf', Neophilologus 61 (1977), 176; F. Klaeber, 'Aeneis und Beowulf', Archiv für das Studium der neueren Sprachen (und Literaturen) 126 (1911), 339-59, at 348; and D. Anlezark, 'Poisoned Places: the Avernian Tradition in Old English Poetry', ASE 36 (2007), 103-26). Similarly, Andy Orchard discusses it in the context of Liber monstrorum in his Pride and Prodigies: Studies in the Monsters of the Beowulf-Manuscript (Cambridge, 1995), at p. 111. For varying religious contexts, see S. Viswanathan, 'On the Melting of the Sword: wcel-rápas and the Engraving on the Sword-Hilt in Beowulf', $P Q 58$ (1979), 360-3; T. D. Hill, 'The Tropological Context of Heat and Cold Imagery in Anglo-Saxon Poetry', NM 69 (1968), 522-32; and P. Beekman Taylor, Sharing Story: Medieval Norse-English Literary Relationships (New York, 1998), at p. 85. For more on the melting of frost and the winter type-scene, see Cavell, 'Weaving and Binding', pp. 80-93. 
${ }^{91}$ Although note that Zachary Hines attributes the melting of the sword to the runes engraved upon it. He links this passage to several Old Norse examples where blood activates rune magic, arguing that the blood of Grendel's mother imbues the sword with enough power to penetrate Grendel's skin. The blood of Grendel then activates the runes a second time, causing the blade to melt. See 'Swords that Speak and Runes that Fight: the Power of the Giant's Sword in Beowulf', Stet 1 (Oct. 2010), 1-17. However, he bases his argument on a reading of line 1570 in which the bright light that accompanies Grendel's mother's beheading emanates from the sword rather than the cave (as does M. Puhvel, 'The Deicidal Otherworld Weapon in Celtic and Germanic Mythic Tradition', Folklore 83.3 (Autumn, 1972), 210-19, at 215-16). Because Hines provides no evidence, I do not find convincing his statement that standan 'expresses direction when paired with a subject such as lēoht'. 'Swords that Speak', 12. Although Bosworth and Toller note that standan is invoked in relation to direction, this is generally only the case when prepositions such as of or geond are also present. See J. Bosworth and T. N. Toller, An Anglo-Saxon Dictionary (Oxford, 1898), Supplement by T. N. Toller (Oxford, 1921), digital edition (Prague, 2010) <http://bosworth.ff.cuni.cz/>, s.v. Similarly, Puhvel's assertion that the previous description of light in the cave at lines 1516b17 makes this one redundant is unconvincing; the previous occurrence describes the light of flames, while this one describes otherworldly and supernatural light, which presumably is much brighter than the flickering light given off by fire in a cave (thus the fight does not take place 'in full light' as he asserts). 'Deicidal Otherworld Weapon', 215.

${ }^{92}$ Lines 847-9: 'There the water was welling with blood, the terrible swirl of the waves, entirely mixed with hot gore, welled with sword-blood'.

${ }^{93}$ Lines 1422-3a: 'The water welled with blood, hot gore - the people looked on'.

${ }^{94}$ For Exodus, see also lines 478 and 573. For Andreas, see lines 954a, 1240 and 1275b-7a. Alison M. Powell discusses the formulaic overlap in these passages in 'Verbal Parallels in 
Andreas and its Relationship to Beowulf and Cynewulf' (unpubl. PhD dissertation, Univ. of Cambridge, 2002), pp. 135-7. An additional poetic collocation of blod and flod occurs in Solomon and Saturn I, lines 155-7, in which the devil carries out all manner of evils, including killing a horse in a river. Blood is also associated with heat in prose; see $D O E$, s.v. blod, sense A.2.a.i.

${ }^{95}$ Lines 1605b-11: 'Then the sword, the battle-blade, began to dissolve into combat-icicles from the war-blood; it was a wonder that it melted entirely, most like ice, when the father loosens the bonds of frost, unwinds the flood-ropes, he who has power over seasons and times; that is the true creator'.

${ }^{96}$ See Viswanathan, 'On the Melting of the Sword', 360-3; Hill, 'Tropological Context of Heat and Cold', 522-32; and Cavell, 'Weaving and Binding', pp. 80-93.

${ }^{97}$ Line 897b: 'the hot dragon melted'.

${ }^{98}$ Lines 1120b-2: 'The heads melted, the wound-openings burst when blood sprang out, the hostile bites of the body; flame swallowed everything'. See also Beowulf's own funeral fire at lines 3143-8a, which, although it does not include an instance of meltan, refers to the fire's heat causing the body to break. Owen-Crocker's fascinating analysis points to the horror element in these scenes, which she discusses in relation to whether or not they provide realistic descriptions of funeral pyres. See The Four Funerals in Beowulf (Manchester, 2000), pp. 53-5.

${ }^{99}$ Here I refer to the simile that describes Grendel's eyes:

$$
\text { him of eagum stod }
$$

ligge gelicost leoht unfæger.

Lines 726b-7: 'from his eyes stood an unpleasant light, most like fire'. Orchard notes a parallel to this descriptor in Liber monstrorum and The Wonders of the East. See Pride and Prodigies, p. 111. 
${ }^{100}$ Lines 1615b-7: 'the sword had melted, the patterned-sword burned up; that blood was too hot, the poisonous alien creature who died therein'. Beowulf echoes this passage when he later relates his tale to the Danes at lines 1666b-8a.

${ }^{101}$ Lines 2711b-15a: 'Then the wound, which the earth-dragon had earlier wrought on him, began to burn and swell; he immediately discovered that in his breast there welled an evil wound, poison from within'. See also lines 978b-80a of Guthlac B, which describe the saint's illness in similar terms.

${ }^{102}$ Interestingly, this diction also overlaps with Anglo-Saxon understandings of the working of the mind and emotions. See L. Lockett, Anglo-Saxon Psychologies in the Vernacular and Latin Traditions (Toronto, 2011), pp. 59-62. At p. 5, Lockett develops previous readings of such 'welling' terminology (such as, J. Potter, “Wylm' and 'weallan' in Beowulf: a Tidal Metaphor', Medieval Perspectives 3 (1988), 191-99) to argue for a hydraulic model of the mind: 'a loose psycho-physiological pattern, in which psychological disturbances are associated with dynamic changes of pressure and temperature in the chest cavity'. ${ }^{103}$ Lines 1457-60a: 'Hrunting was the name of the hilted blade; that was one of the foremost of old treasures; the edge was iron, stained/adorned with poison-twigs, hardened with battleblood'.

${ }^{104}$ See W. Cooke, 'Three Notes on Swords in Beowulf', MAE 72 (2003), 302-7; Beekman Taylor, Sharing Story, p. 87; and Hines, 'Swords that Speak'. For Sigrdrifomál, see Edda: die Lieder des Codex Regius nebst Verwandten Denkmälern, ed. G. Neckel, 2 vols (Heidelberg, 1962-1968) I, 191, stanza 6.

${ }^{105}$ See Klaeber Four, p. 205; and Brady, 'Weapons in Beowulf', 101-2.

${ }^{106}$ See Sword in Anglo-Saxon England, p. 129-32.

${ }^{107}$ Ibid. p. 131-2.

${ }^{108}$ Ibid. 
${ }^{109}$ See 'Haben die Germanen vergiftete Schwerter verwendet?', Arkiv för nordisk filologi 68 (1953), 179-81, at 181.

${ }^{110}$ See above, n. 87, as well as A. P. Church, 'Beowulf's "ane ben" and the Rhetorical Context of the "Hunferth Episode", Rhetorica 18 (2000), 49-78; C. J. Clover, 'The Germanic Context of the Unferp Episode', Speculum 55.3 (July, 1980), 444-68; M. J. Enright, 'The Warband Context of the Unferth Episode', Speculum 73.2 (April, 1998), 297337; Greenfield, 'Extremities of the Beowulfian Body Politic', p. 7; J. D. A. Ogilvy, 'Unferth: Foil to Beowulf?', PMLA 79.4 (Sept., 1964), 370-5; W. Parks, 'Flyting and Fighting: Pathways in the Realization of the Epic Contest', Neophilologus 70 (1986), 292306; W. Parks, 'The Flyting Speech in Traditional Heroic Narrative', Neophilologus 71 (1987), 285-95; and P. Silber, 'Rhetoric as Prowess in the Unferð Episode', Texas Stud. in Lit. and Lang. 23.4 (Winter, 1981), 471-83.

${ }^{111}$ The Battle of Maldon, ed. D. G. Scragg (Manchester, 1981), lines 46-8: 'They wish to give you spears as tribute, a poisonous point and old swords, the war-gear which is not a benefit for you in battle'.

${ }^{112}$ Ibid. lines 144b-6a: 'he was wounded in the breast, through that ring-enclosure; at his heart stood a poisonous point'.

113 See p. 205.

114 See sense 1.b.

${ }^{115}$ Lines $1330 \mathrm{~b}-2 \mathrm{a}$ : 'Let the point of the spear, the arrow marked/stained by poison, pierce the life of the doomed one'.

${ }^{116}$ s.v. attor, ator, sense 2.

${ }^{117}$ See above, p. 20.

${ }^{118}$ See gloss 2063 in J. J. Quinn, 'The Minor Latin-Old English Glossaries in MS. Cotton Cleopatra A.III' (unpubl. PhD dissertation, Stanford Univ., 1959), p. 215. 
${ }^{119}$ C. T. Lewis and C. Short, A Latin Dictionary: Founded on Andrews' Edition of

Freund's Latin Dictionary (Oxford, 1879), s.v. lino.

${ }^{120}$ See Opera Omnia Aldhelmi, ed. R. Ehwald, MGH SS Auct. antiq. XV (Berlin, 1919), p. 457, line 2575: 'carrying bloody weapons and spears smeared with poison'; DOE, s.v. attor, ator, sense 2 .

${ }^{121}$ See lines 33-9.

${ }^{122}$ Lines 766-71a: 'Therefore we must always keep guard firmly and cautiously against that sudden shot, lest the poisonous point, the painful missile, the sudden artifice of fiends, should enter under the bone-enclosures. That is a deadly wound, the most dangerous of injuries'. ${ }^{123}$ S.v. attor, ator, sense 2.b.

${ }^{124}$ See above, p. 19.

${ }^{125}$ Line 468b-2a: 'Often I deprived sight, blinded with evil-thoughts a countless amount of men from the race of humans, snatched away the light of their eyes with a covering of mist, by means of a poisonous point in dark showers'.

126 'Body, Self and Text', p. 206. Elsewhere, however, Jagger discusses Cynewulf's development of body-kennings into 'a more metaphoric and experimental mode of expression that is enriched by the influence of Christian literary tradition'. See p. 151.

${ }^{127}$ Lines 1563-9: 'Then he seized the weapon-hilt, the protector of the Scyldings, rough and sword-grim, he drew the ring-marked one, despairing of life, struck angrily, so that it grasped hard at her neck, broke the bone-rings; the point drove entirely through the doomed fleshhome, she fell to the floor; the sword was bloody, the warrior/blade rejoiced in his work'. ${ }^{128}$ Although, one might speculate that Grendel's blood only becomes corrosive after it has remained hot in a dead — and presumably cold — body, which his mother's has not yet had the chance to do.

${ }^{129}$ See Cavell, 'Weaving and Binding', pp. 80-93; and Hines, 'Swords that Speak', 13. 
${ }^{130}$ Indeed, this may relate to an implicit gendering of the characters, Grendel's mother's body being less terrifying than the male body of her son, as noted above, p. 15 .

${ }^{131}$ Cohen, 'Monster Culture', p. 7.

${ }^{132}$ I would like to thank Richard Dance, Matthias Ammon, Rebecca Merkelbach and my anonymous reviewers for reading earlier versions of this paper and providing helpful feedback. 